\title{
Model Proses Bisnis ERP, Pengendalian Manajemen dan Keunggulan Kompetitif
}

\section{ERP Business Process Model, Management Control and Competitive Advantage}

\author{
Muhammad Nawawi* \& Dabella Yunia \\ Program Studi Akuntansi, Fakultas Ekonomi dan Bisnis, Universitas Sultan Ageng Tirtayasa, \\ Indonesia \\ *Coresponding Email: muhammadnawawi@untirta.ac.id
}

\begin{abstract}
Abstrak
Penelitian ini bertujuan untuk memberikan bukti empiris tentang model proses bisnis ERP terhadap keunggulan kompetitif. Khususnya, penelitian ini menginvestigasi efek mediasi dari pengendalian manajemen dalam hubungannya antara implementasi ERP dan keunggulan kompetitif. Analisis empiris dalam penelitian ini didasarkan pada data primer yang diperoleh dari survei terhadap manajer dari 50 perusahaan manufaktur dengan tingkat respons 33,67\%. Penelitian ini dilakukan melalui metode pendekatan structural equation modelling (SEM) dengan alat pengujian partial least squares (PLS). Secara langsung, temuan ini memperlihatkan implementasi ERP memiliki dampak positif terhadapkeunggulan kompetitif perusahaan, denganmeningkatkan kesempatan inovasi yang melibatkan pembangunan kapasitas lebih besar yang menciptakan manfaat peluang jangka panjang dan keunggulan kompetitif yang berkelanjutan. Penggunaan pengendalian informal cenderung lebih terintegrasi dengan sistem informasi dalam menghasilkan informasi yang lebih berkualitas untuk mendukung pengambilan keputusan sehingga memediasi pengaruh positif dari implementasi ERP dalam meningkkatkan keunggulan kompetitif perusahaan. Sedangkan pengendalian formal tidak dapat menjadi mediator yang baik ketika tidak disertai dengan penambahan atribut bisnis lain.

Kata Kunci: Pengendalian Manajemen Formal; Pengendalian Manajemen Informal Keunggulan Kompetitif.
\end{abstract}

\begin{abstract}
This study aims to provide empirical evidence about the ERP business process model of competitive advantage. In particular, this study investigates the mediating effect of management control on the relationship between ERP implementation and competitive advantage.The empirical analysis in this study is based on primary data obtained from a survey of managers of 50 manufacturing companies with a response rate of $33.67 \%$.This research was conducted with a structural equation modeling (SEM) approach method with testing tools using partial least squares (PLS).Directly, these findings suggest ERP implementation has a positive impact on a firm's competitive advantage, by increasing innovation opportunities that involve building greater capacity that creates long-term benefit opportunities and sustainable competitive advantage.The use of informal controls tends to be more integrated with information systems in producing higher quality information to support decision making so as to mediate the positive effect of ERP implementation in increasing the company's competitive advantage.Meanwhile, formal control cannot be a good mediator when it is not accompanied by the addition of other business attributes.

Keywords: Formal Management Control; Informal Management Control; Competitive Advantage. How to Cite: Nawawi, M., \& Yunia, D. (2021). Model Proses Bisnis ERP, Pengendalian Manajemen dan Keunggulan Kompetitif. Jurnal Akuntansi dan Bisnis : Jurnal Program Studi Akuntansi. 7 (1): 11-22.
\end{abstract}




\section{PENDAHULUAN}

Saat ini, analisis data dan bisnis yang melibatkan pengolahan data dalam jumlah besar memainkan peran penting dalam setiap aspek perusahaan untuk pengambilan keputusan, analisis strategis, dan prediksi. Hal ini memungkinkan jutaan elemen data yang akan dibuat, diekstrak, dikumpulkan, diproses, dan dianalisis dari sumber internal atau eksternal untuk mempertahankan keunggulan kompetitif (Griffin \& Wright, 2015). Sistem ERP adalah sistem informasi yang terintegrasi dalam suatu organisasi memainkan peran penting dalam mengawasi dan mengkoordinasikan semua sumber daya perusahaan, fungsi dan informasi dalam satu database, sehingga meningkatkan kemampuan akuntan manajemen untuk memenuhi dan menyediakan akses real-time dan data operasional yang relevan untuk mendukung pengendalian manajemen dan pengambilan keputusan bertujuan meningktakan efisiensi organisasi (Kallunki dkk, 2011; Appelbaum dkk, 2017).

Sebagai sumber daya penting bagi perusahaan, sistem ERP dapat menggabungkan transaksi perusahaan dan informasi ke dalam satu database bersama yang memungkinkan informasi dapat diakses oleh departemen/divisi yang berbeda, dengan demikian dapat meningkatkan kemampuan akuntan manajemen untuk memenuhi peran mereka dalam menyediakan datareal-time, khususunya data operasional yang mendukung pengendalian manajemen dan pengambilan keputusan (Appelbaum dkk, 2017; Alomari dkk, 2018). Hal ini membuat sistem ERP menjadi hal penting untuk diimplementasikan oleh perusahaan dalam mencapai keunggulan kompetitif (Chae dan Olson, 2013) yang akan memiliki efek besar pada pengendalian manajemen dan kinerja perusahaan (Gorla dkk, 2010.).

Dalam mencapai keunggulan kompetitif perusahaan denganimplementasi ERP, pengendalian manajemen telah diidentifikasi sebagai salah satu faktor penting menuju keberhasilan implementasi sistem ERP (Ruivo dkk, 2014). Chenhall (2003) dan Kallunki dkk (2011) mendefinisikan pengendalian manajemen(formal dan informal) sebagai pendekatan yang dirancang membantu dalam pengambilan keputusan manajemen. Selain itu, pengendalian manajemen berfungsi sebagai prasyarat dalam membantu pengambilan keputusan manajer di seluruh organisasi dan membimbing perilaku pegawai dalam caracara yang tepat untuk meningkatkan peluang dalammencapai tujuan organisasi, kinerja, dan daya saing (Bhimani dkk., 2008; Ruivo dkk, 2014). Meskipun dalam beberapa beberapa hasil studi yang ditemukan masih ada perbedaan, teknologi informasi terbukti memiliki efek luar biasa pada pengendalian manajemen (Granlund 2011).

Kalllunki dkk. (2011) meneliti tentang dampak implementasi ERP pada kinerja perusahaan dan sistem pengendalian manajemen. Pada peneitian ini, implementasi ERP berpengaruh secara langsung terhadap kinerja perusahaan namun tidak signifikan. Hasil pengaruh yang signifikan ddidapat ketika ada perantara dari sistem pengendalian manajemen. Dari dua jenis sistem pengendalian manajemen yang diklaisifikasikan sebagai sistem pengendalian manajemen formal dan sistem pengendalian manajemen informal, pengaruh signifikan diperoleh ketika pengendalian formal dijadikan sebagai perantara, tetapi pengendalian manajemen informal tidak memberikan dampak yang signifikan ketika dijadikan sebagai perantara implementasi ERP terhadap kinerja perusahaan.Alomari dkk. (2018) meneliti tentang dampak implementasi ERP terhadap keunggulan kompetitif. Pada penelitian implementasi ERP sebagai transformasi dari sistem teknologi dan informasi perusahaan berpengaruh signifikan terhadap keunggulan kompetitif perusahaan karena dapat memberikan informasi secara lengkap, rinci dan real-time yang dapat digunakan sebagai alat pengambilan keputusan manajemen.

Penelitian ini mengacu penelitian dari Kallunki dkk (2011) dan Alomari dkk (2018) dengan mengunakan variabel pengendalian manajemen sebagai perantara dalam proses implementasi ERP pada keunggulan kompetitif. Alasan peneliti menambahkan variabel 
pengendalian manajemen adalah jika pengendalian manajemen dapat menjadi perantara yang signifikan dari proses implementasi ERP pada kinerja perusahaan, maka dapat memungkinkan berpotensi menjadi penguat daya saing yang unggul untuk perusahaan setelah kinerjanya meningkat.

"Implementasi ERP, merupakan kemampuan perusahaan dalam melakukan adaptasi, menyusun, dan mengintegrasikan arus informasi dan proses bisnis. Meskipun perusahaan dapat mengimplementasikan ERP, maka kebutuhan untuk beradaptasi, rekonfigurasi, dan mengintegrasikan arus informasi dan proses bisnis secara berkelanjutan dikarenakan perubahan pasar dan teknologi baru diciptakan" (Hong dkk., 2010). Sukses implementasi ERP melibatkan perancangan ulang proses bisnis dari sebuah orientasi, tidak fleksibel, orientasi transaksi-masal menjadi proses yang gesit, ramping, dan knowledgebased (Tsai dkk., 2010). Ide utama ERP adalah mengelola konsep logistik dari persyaratan bahan perencanaan (MRP) dan manufaktur perencanaan sumber daya (MRP II). Sebagai pilihan untuk memanfaatkan beberapa sistem dalam mengelola perusahaan dan bisnis,susuai fungsi ERP sebagai sumber informasi perusahaan yang menggabungkan sistem tradisional perusahaan dan operasi dalam satu basis data yang terintegrasi (Alomari dkk, 2018). Hal ini memungkinkan arus informasi untuk dibagikan dengan menghasilkan proses efisiensi bisnis yang tinggi, pelaporan berkualitas, dan mudah.

ERP memfasilitasi transaksi proses bisnis di perusahaan-perusahaan untuk lebih baik mengelola mereka operasi dengan cara untuk menciptakan keunggulan kompetitif (Kharabe\& Lyytinen, 2012). Dari beberapa studi literatur yang pernah ada, Sanchez dan Spraakman (2012) mencoba untuk memberikan pemahaman yang jelas tentang implementasi ERP dan dampaknya terhadap akuntansi dan pengendalian manajemen. Mereka menemukan bahwa standarisasi sistem yang diperluas memungkinkan untuk departemen dan fungsi lain dalam manajemen meningkatkan akurasi informasi, ketepatan waktu dan tingkat produksi yang lebih baik. Singkatnya, empat atribut ini adalah manfaat dari ERP (a) tepat waktu dan informasi yang lebih akurat (b) peningkatan ketersediaan informasi perusahaan yang terintegrasi (c) dan mengurangi jumlah entri data yang dilakukan oleh akuntan manajemen.

Pengendalian manajemen terdiri sistem kontrol ganda yang saling bergantung dan bekerja sama untuk membentuk suatu paket kontrol yang efisien untuk meningkatkan kinerja organisasi (Malmi dan Brown, 2008). Tujuan utama dari MCS yaitu memberi informasi yang berguna untuk perencanaan, pembuatan keputusan, dan evaluasi, sehingga dapat mengontrol keputusan yang diambil di seluruh bagian organisasi dan menjadi standar operasional untuk membantu organisasi mencapai tujuan (Bhimani dkk, 2008). Hal ini dilakukan dengan mengontrol dan memenuhi kebutuhan informasiserta meningkatkan kinerja individu dengan kriteria penilaian tertentu (Cuguero-Escofet \& Rosanas, 2013). Sampai saat ini, pengendalian manajemen telah dibahas dan dipelajari dari perspektif yang berbeda, maka dengan itu definisi tunggal tentang pengendalian manajemen masih belum ada (Helsen dkk., 2017). Pengendalian manajemen berfokus pada perilaku pekerja, output atau pikiran karyawan yang terdiri dari alat untuk menentukan, memantau dan mengevaluasi tindakan individu dan kelompok.

Sebuah tema umum dalam organisasi dan bisnis studi adalah bentuk kontrol organisasi dan manajemen yang didasarkan pada keyakinan bahwa pengendalian manajemen dapat dicapai adalah hal penting. Meskipun saran dari beragam bentuk pengendalian itu adalah umum untuk menempatkan penekanan pada bentuk utama dari pengendalian, baik itu dalam bentuk struktur organisasi tertentu atau dalam bentuk pengendalian lain (Caker dan Siverbo, 2014). Sebagai salah satu alternatif bentuk 
pengendaliana manajemen yang pernah ada adalah menggabungkan semua jenis pengendalian ke dalam dua label utama seperti pengendalian manajemen formal dan informal (Kallunki dkk, 2011; Caker dan Siverbo, 2014).

"Keunggulan kompetitif perusahaan merupakan kemampuan perusahaan yang terus dikembangkan oleh sumber daya internal yang meliputi dukungan struktur organisasi, kekuatan finansial, motivasi internal serta kelengkapan teknologi informasi untuk mengembangkan kekuatan dan inovasi yang terus diciptakan dan memiliki daya saing di pasar" (Noruzy dkk. 2013).Akhirnya, kemampuan informasi menandakan kecanggihan teknologi yang menggambarkan, mengatur, mengintegrasikan, dan akses data, yang diperlukan untuk menciptakan keunggulan kompetitif melalui meningkatnya transparansi informasi dan efisiensi pengambilan keputusan (Hazen dkk. 2016).

Awwad dkk. (2013) mengemukakan "keunggulan bersaing adalah kemampuan yang diperoleh melalui karakteristik dan sumber daya suatu perusahaan untuk mencapai kinerja yang lebih tinggi dibandingkan perusahaan lain pada industri atau pasar yang sama." Keunggulan kompetitif ditimbulkan oleh kemampuan perusahaan yang mampu memanfaatkan kekuatan internal untuk merespon peluang dari luar perusahaan atau pasar.

Perusahaan berinvestasi dalam sistem ERP mengharapkan untuk mencapai tujuan mereka dan mengembangkan kemampuan perusahaan dan sumber daya bersama-sama dengan keterampilan teknis dan manajerial dalam rangka menciptakan keunggulan kompetitif yang berkelanjutan (Alomari dkk, 2019). Penerapan sistem ERP akan membawa manfaat operasional dengan meningkatkan kesempatan inovasi yang melibatkan pembangunan kapasitas lebih besar yang menciptakan manfaat peluang untuk jangka panjang, menghasilkan keunggulan kompetitif yang berkelanjutan (Molla dan Bhalla, 2006). Sebelumnya, penelitian telah menyoroti signifikasi integrasi yang diciptakan dengan penerapan sistem ERP untuk mencapai keunggulan kompetitif (Botta-Genoulazdkk. 2005) dengn bukti peningkatan keunggulan kompetitif yang diciptakan oleh integrasi proses bisnis ERP.

Keunggulan kompetitif dicapai dengan perubahan utama perilaku dan budaya perushaan yang didukung melalui sistem kerja ERP. Selain itu juga, telah dikemukakan Lengnick dkk. (2004) bahwa sistem ERP membuka jalan investasi modal intelektual organisasi yang menghasilkan keunggulan kompetitif. Selain itu, disarankan oleh Zhang dkk. (2005) perusahaan di bidang manufakturmemilih sistem ERP sebagai pilihan yang diterima luas untuk pencapaian keunggulan kompetitif meskipun dalam beberapa hal masih diperdebatkan.Alomari dkk. (2018) mengemukakan bahwa kinerja kompetitif dari suatu perusahaan dapat ditingkatkan dengan mengintegrasikan seluruh fungsi internal organisasi yang menghubungkan proses operasi internal dan eksternal yang efektif. Hasil tersebut didukung oleh Bhatt dan Grover (2005) yang menyatakan bahwa keahlian menggunakan teknologi informasi bisnis bersama dengan infrastruktur kemitraan bisnis yang terintegrasi dan mudah digunakan akan membuka jalan untuk pencapaian keunggulan kompetitif.

Melalui integrasi ERP, dengan didukung kecanggihan teknologi informasi yang maju akan menyebabkan peningkatan daya saing dan keterbukaan informasi dengan pelanggan (Mzoughi dkk. 2008). Evolusi sistem ERP sejak penampilan pertama mereka di pasar perangkat lunak di tahun sembilan puluhan secara bertahap digunakan oleh perusahaan dengan ukuran perusahaan yang berbeda, fenomena ini pernah dipelajari oleh beberapa peneliti yang mengamati hubungan ERP dan keunggulan kompetitif (Kallunki dkk, 2011; Alomari dkk. 2019).Sebagai sebuah sistem, ERP berfungsi sebagai alat yang efektif dalam memastikan keunggulan kompetitif dalam jangka panjang untuk meningkatkan kinerja 
perusahaan (Hu, 2015; Mzoughi dkk. 2016). Sesuai dengan penjelasan di atas, diusulkan hipotesis berikut:

H1: Penggunaan ERP yang intensif memiliki pengaruh langsung positif pada keunggulan kompetitif.

Pengendalian manajemen sangat penting dalam memastikan keunggulan kompetitif perusahaan. Sebagai besar, pengendalian manajemen menjadi alat kunci yang digunakan manajer untuk beberapa aspek tujuan yang berbeda diantaranya penganggaran, perencanaan, pengukuran, menganalisis dan mengevaluasi untuk memberi informasi yang berguna dalam pengambilan keputusan yang rasional (Simons, 2000). Selain itu, efektivitas pengendalian manajemenbaik formal ataupun informal berfungsi sebagai perangkat yang mengarah ke peningkatan kinerja perusahaan (Kallunki dkk. 2011). Thomas dkk. (2012) menyatakan "penerapan ERP berpengaruh terhadap kinerja keuangan dan non-keuangan seperti meningkatkan produktivitas, meningkatkan ketepatan waktu pengiriman dan akurasi pelaporan." Perusahaan memberikan perhatian khusus terhadap bentuk implementasi penegndalian manajemen sebagai alat yang dibutuhkan untuk berkontribusi dalam kesuksesan bisnis dan keunggulan kompetitif (Alomari dkk. 2018). Oleh karena itu, ERPberfungsi sebagai payung untuk sistem penegndalian manajemen dengan tujuan meningkatkan kinerja organisasi. Terlepas dari kenyataan bahwa ERP dapat dianggap sebagai perangkat lunak teknis, namun keberadaannya dapat membawa perbaikan kinerja yang optimal pada organisasi.

Secara keseluruhan, beberapa studi literatursebelumnya menunjukkan pengaruh dari penggunaan pengendalian manajemen sebagai 'proses organik' pada kinerja suatu organisasi dalam menghasilkan keunggulan kompetitif (Sanchez dan Spraakman, 2012). Sebaliknya, beberapa studi menunjukkan bahwa terlepas dari potensi yang signifikan dari ERP, mempertahankan sistem pengendalianmanajemen yang sudah ada sebelumnya tanpa menyesuaikan dengan sistem ERP masih dapat menjadi pilihan perusahaan (Rom dan Rohde, 2007).Hal ini dikemukakan oleh Scapens dan Jayazeri (2003)bahwa tidak ada perubahan yang signifikan meskipunERP diimplementasikan karena pilihan yang diambil oleh manajer adalahmempertahankan pengendalian manajemen yang sudah ada. Beberapa studi menemukan peran penting dari dukungan manajemen dalam memberikan proses keberhasilan implementasi ERP (Rom \& Rohde, 2007). Granlund dan Malmi, (2002) menemukan hasil yang sama di mana prinsip-prinsip yang ada pada pengendalian manajemen hanya dipindahkan ke sistemERP yang menunjukkan sedikit perubahan.

Dampak signifikan dari sistem ERP pada pengendalian manajemen telah dipelajari oleh Kallunki dkk. (2011) dengan menunjukkan hasil penelitian dengan peningkatan kinerja keuangan dan non-keuangan pada implementasi ERP. Chapman dan Kihn (2009) mengemukakan integrasi sistem informasi memungkinkan sistem penganggaran dan penegendalian manajemen formal dapat meningkatkan kualitas informasi pengambilan keputusan. Oleh karena itu ERP berfungsi sebagai platform untuk penggunaan yang lebih luas pada dua pengendalian manajem formal dan informal (Kallunki dkk. 2011; Alomari dkk. 2018).

H2a: Penggunaan ERP yang intensif memiliki pengaruh langsung positif pada pegendalian manajemen formal.

H2b: Penggunaan pengendalian manajemen formal secara intensif memediasi pengaruh langsung positif dari sistem ERP pada keunggulan kompetitif perusahaan.

H3a: Penggunaan ERP yang intensif memiliki pengaruh langsung positif pada penegndalian manajemen informal. 
H3b: Penggunaan pengendalian manajemen informal secara intensif memediasi pengaruh langsung positif dari sistem ERP pada keunggulan kompetitif perusahaan.

\section{METODE PENELITIAN}

Data penelitian ini yaitu data primer berbentuk persepsi responden dihimpun melalui mail survey atau survey elektronik menggunakan aplikasi google document dan melalui contact person langsung melalui nomor telepon yang didapat dari data Dinas Perindustrian dan Perdagangan (DISPERINDAG) Provinsi Banten dan Dinas Penanaman Modal dan Pelayanan Terpadu Satu Pintu (DPMPTSP) Provinsi Banten.

Populasi penelitian ini sejumlah 50 (lima puluh) perusahaan manufaktur yang menerapkan sistem ERP di Provinsi Banten yang telah menerapkan ERP minimal dua tahun (Nicolaou, 2004). Alasan pemilihan lokasi penelitian yaitu populasi manajer pada perusahaan yang menerapkan sistem ERP di Provinsi Banten sangat banyak karena terdiri dari kawasan industri besar dengan banyak perusahaan dalam negeri dan perusahaan multinasional, sehingga dianggap mampu menggeneralisasi permasalahan dalam penelitian. Responden di penelitian ini yaitu manajer yang bertanggung jawab dalam hal keuangan perusahaan seperti manajer keuangan dan manajer akuntansi. Menurut Widener (2007) "pemilihan sampel manajer yang bertanggung jawab dalam hal keuangan karena mereka memiliki pengetahuan tentang tentang sistem informasi dan sistem pengendalian perusahaan tersebut, selain itu karena mereka juga menempati posisi di mana mereka memiliki pngetahuan tentang isu-isu strategis." Diasumsikan tingkat response rate pada penelitian ini yaitu 15\%. Ghozali (2011) mengemukakan "response rate di Indonesia umumnya berkisar antara 10\% sampai dengan 16\%." Chin dan Newsted (1999) dalam Mahama (2006) menyarankan "dalam menentukan sampel yang memadai untuk partial least square (PLS), ada dua kemungkinan, yaitu: konstruk dengan jumlah yang paling besar dari pengukuran formatif atau konstruk endogen memiliki jumlah yang lebih besar dibandingkan konstruk eksogen oleh karena itu ukuran sampel seharusnya sama total konstruk endogen dikali sepuluh, oleh karena konstruk endogen dalam penelitian ini adalah 4 (empat) maka dikalikan sepuluh yang berarti sampel minimal adalah 40 (empat puluh)."

Variabel Independen: Enterprise Resources Planning (ERP). "Konstruk ERP diukur berdasarkan sistem keuangan, logistik, manajemen persediaan, manajemen produk dan manufaktur, serta manajemen sumber daya manusia" yang telah dikembangkan oleh Kallunki dkk.(2011) dengan 6 (enam) petanyaan survey. memakai skala likert 7 dari nilai satu jika tidak digunakan sama sekali pada perusahaan hingga nilai 7 apabila sangat intensif digunakan pada perusahaan.

Variabel Intervening: Pengendalian Manajemen Formal (PMF) dan Pengendalian Manajemen Informal (PMI). Konstruk pengendalian manajemen formal diukur bedasarkan instruksi, pembagian kerja, prosedur standar operasi, panduan manual, dan aturan etika. dengan 5 (lima) item pernyataan dengan memakai skala likert 7 dari nilai satu apabila sangat tidak setuju hingga nilai tujuh jika sangat setuju sekali. Pengendalian manajemen informal diukur berdasarkan etos kerja, gaya manajemen, dan budaya perusahaan dengan 4 (empat) item pernyataan dengan memakai skala likert 7 dari nilai satu apabila sangat tidak setuju hingga nilai tujuh apabila sangat setuju sekali berdasarkan pengembangan dari penelitian Anthony dan Govindarajan (2007); Kallunki dkk. (2011).

Variabel Dependen: Keunggulan Kompetitif (KK). Konstruk keunggulan kompetitif diukur berdasarkan pada kesesuaian produk, ketersediaan produk, biaya produksi, inovasi produk, dan aksesibilitas layanan purna jual yang telah dikembangkan oleh Chenhall.(2005); Alomari dkk. (2019), dengan 5 (lima) pernyataan dengan memakai 
skala likert 7 dari nilai satu apabila sangat tidak setuju hingga nilai 7 apabila sangat setuju sekali.

Di dalam penelitian ini untuk menyelesaikan permasalahan yang ada digunakan beberapa prosedur teknik analisis data dengan analisis SEM dengan program SmartPLS versi 3.0. SEM-PLS dipilih karena sesuai untuk model penelitian ini yang memakai variabel yang tidak bisa diukur secara langsung (latent variables) dengan tahapan pengujian:1) uji reliabilitas dengan kriteria uji Composite Reliability. "Indikator dapat dikatakan valid jika angka dari perhitungan olah data lebih besar dari sama dengan 0,70" (Hair dkk. 2016). 2) uji validitas dilakukan dengan membandingkan nilai AVE setiap konstruk dengan korelasi antara konstruk dengan konstruk lainnya dalam model. "Apabila nilai akar kuadrat dari AVE setiap konstruk lebih besar daripada nilai korelasi antara konstruk lainnya dalam model, maka masing-masing indikator pernyataan adalah valid" (Hair dkk. 2016). 3) uji hipotesis bisa dilihat melalui nilai t-statistik, batas untuk menolak atau menerima hipotesis yang diajukan yaitu 1,96. "Apabila nilai $t$ berada di bawah 1,96 maka hipotesis akan ditolak atau dengan kata lain menerima hipotesis nol ( $\left.\mathrm{H}_{0}\right)$ ” (Ghozali, 2011; Hair dkk. 2016).

\section{Tingkat Respon dan Karakteristik Sampel}

\section{HASIL DAN PEMBAHASAN}

Dari 98 kuesioner yang dikirim, kuesioner yang kembali sebanyak 36 eksemplar dan kuesioner yang dapat dipakai dalam pengolahan data sebanyak 33 kuesioner dengan tingkat respon sebesar 33,67\%, 3 kuesioner tidak dapat digunakan karena jawaban tidak lengkap. Menurut Ghozali (2011), "tingkat respon penelitian ini cukup tinggi karena pada umumnya tingkat respon survei di Indonesia sekitar 10-20\%."

\section{Pengujian Validitas dan Reliabilitas Konstruk}

"Sesuai dengan prosedur pengujian SEM-PLS, maka evaluasi validitas konvergen konstruk menggunakan indikator berupa loading factor dan average variance extracted (AVE)" (Ghozali, 2011). "Hasil outer model melalui SmartPLS di bawah ini menunjukan kriteria validitas konvergen telah terpenuhi yakni loading factor $>0,70$ dan AVE $>0,60$ " (Ghozali, 2011). Ada tiga pertanyaan/pernyataan yang dieliminasi karena nilainya kurang dari 0,70 .

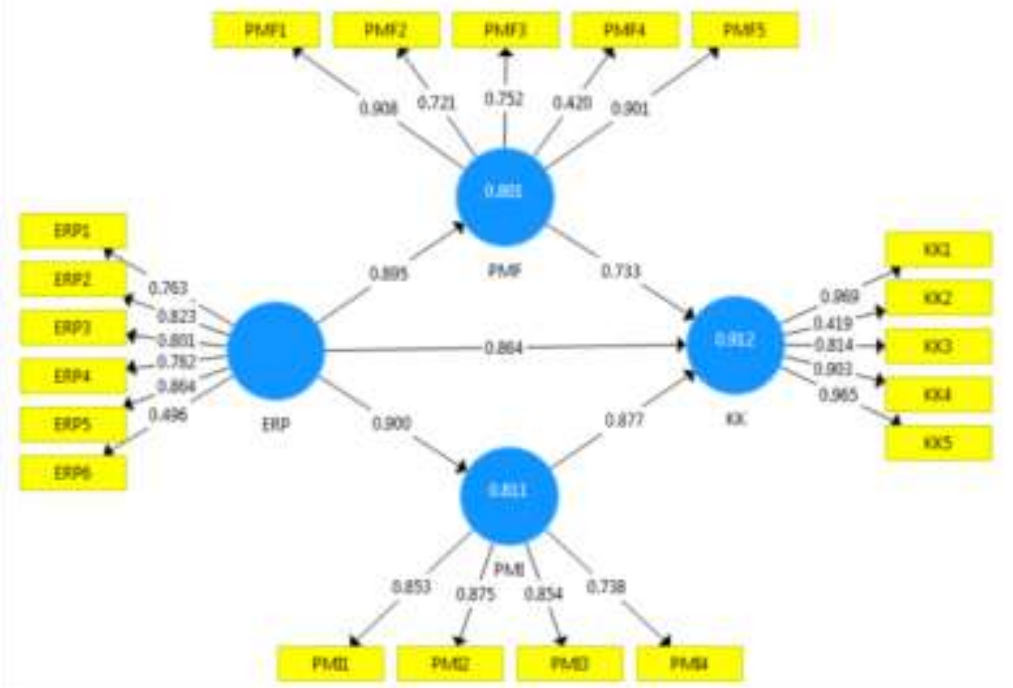

Gambar 1. Hasil outer model melalui SmartPLS Sumber: Data yang diolah 
Tabel 1. Hasil outer model melalui SmartPLS

\begin{tabular}{ccccc}
\hline & ERP & PMF & PMI & KK \\
\hline ERP1 & 0.763 & & & \\
ERP2 & 0.823 & & & \\
ERP3 & 0.801 & & & \\
ERP4 & 0.782 & & & \\
ERP5 & 0.864 & & & \\
ERP6 & $0.496^{*}$ & & & \\
PMF1 & & 0.908 & & \\
PMF2 & & 0.721 & & \\
PMF3 & & 0.752 & & \\
PMF4 & & $0.420^{*}$ & & \\
PMF5 & & 0.901 & & \\
PMI1 & & & 0.853 & \\
PMI2 & & & 0.875 & \\
PMI3 & & & 0.854 & \\
PMI4 & & & 0.738 & \\
KK1 & & & & 0.969 \\
KK2 & & & & $0.419^{*}$ \\
KK3 & & & & 0.814 \\
KK4 & & & & 0.903 \\
KK5 & & & & 0.965 \\
\hline
\end{tabular}

Sumber: Data yang diolah

Penilaian pada discriminant validity di penelitian ini dilakukan dengan perbandingan nilai akar kuadrat AVE dengan nilai korelasi antar konstruk. Tabel di bawah ini menunjukan "kriteria validitas diskriminan sudah terpenuhi dengan nilai akar kuadrat AVE lebih besar daripada koefisien korelasi antar konstruk" pada (Ghozali, 2011; Kock, 2015). Tabel di bawah ini juga menunjukan bagaimana kiteria reliabilitas sudah terpenuhi dengan nilai composite reliabillity setiap konstruk atau variabel laten tersebut di atas 0,7 yang menandakan internal consistency dari antar variabel mempunyai reliabilitas yang baik. Singkatnya, disimpulkan bahwa semua skala berperilaku andal, menunjukkan validitas konvergen dan diskriminatif yang memuaskan dan menunjukkan sifat psikometrik yang memadai (Kock, 2015).

Tabel 2. Composite Reliability

\begin{tabular}{ccccc}
\hline & R-square & $\begin{array}{c}\text { Composite } \\
\text { Reliability }\end{array}$ & AVE & $\sqrt{A V E}$ \\
\hline ERP & 0.000 & 0.892 & 0,894 & 0,946 \\
PMF & 0.801 & 0.867 & 0,816 & 0,903 \\
PMI & 0.811 & 0.899 & 0,832 & 0,912 \\
KK & 0.912 & 0.918 & 0,841 & 0,917 \\
\hline \multicolumn{5}{l}{ Sumber: Data yang diolah }
\end{tabular}




\section{Pengujian Korelasi Antar Konstruk}

Matriks korelasi pada tabel 3, menampakkan ada hubungan positif antara ERP dan pengendalian manajemen formal (PMF) dengan koefisien korelasi yaitu 0,895 dan signifikan. Ada hubungan positif antara ERP dan manajemen informal (PMI) dengan koefisien korelasi yaitu 0,900 dan signifikan. Ada hubungan positif antara ERP dan keunggulan kompetitif (KK) dengan koefisien korelasi yaitu 0,864 dan signifikan. Ada hubungan positif antara PMF dan keunggulan kompetitif (KK) dengan koefisien korelasi yaitu 0,733 dan signifikan. Ada hubungan positif antara PMI dan keunggulan kompetitif (KK) dengan koefisien korelasi yaitu 0,877 dan signifikan "Hasil ini menunjukkan indikasi awal dukungan terhadap hipotesis mediasi karena hubungan mediasi mensyaratkan korelasi signifikan antara variabel independen, pemediasi, dan dependen" (Baron dan Kenny, 1986, Hair et al., 2010).

Tabel 3. Korelasi antar Konstruk

\begin{tabular}{ccccc}
\hline & ERP & PMF & PMI & KK \\
\hline ERP & 0.946 & & & \\
PMF & $0.895^{*}$ & 0.903 & & \\
PMI & $0.900^{*}$ & 0.000 & 0.912 & \\
KK & $0.864^{*}$ & $0.733^{*}$ & $0.877^{*}$ & 0.917 \\
\hline \multicolumn{5}{l}{ Sumber: Data yang diolah } \\
\end{tabular}

\section{Pengujian Hipotesis}

Hasil pengujian dengan menggunakan SmartPLS 3.0seperti yang diperlihatkan dalam gambar dan tabel di bawah ini dihasilkan bahwa penggunaan ERP secara intensif berpengaruh langsung secara signifikan terhadap keunggulan kompetitif dengan nilai tstatistik sebesar 22,949, maka dari itu mendukung hipotesis 1 . Hasil uji hipotesis 2a didukung dengan nilai t-statisik sebesar 19,329, namun hipotesis $2 \mathrm{~b}$ tidak didukung kerena memiliki nilai t-statisik0,753 yang artinya pengendalian manajemen formal tidak memediasi pengaruh tidak langsung ERP terhadap keunggulan kompetitif (Claudya, 2020).Hasil pengujian hiptesis $3 a$ dan $3 \mathrm{~b}$ didukung dengan nilai t-statistik masing-masing sebesar 26,368 dan 5,759.

Tabel 4. Hasil pengujian hipotesis

\begin{tabular}{|c|c|c|c|}
\hline $\begin{array}{c}\text { Path } \\
\text { Construct }\end{array}$ & $\begin{array}{c}\text { Original } \\
\text { sample } \\
\text { estimate }\end{array}$ & $\begin{array}{l}\text { Standard } \\
\text { deviation }\end{array}$ & T-Statistic \\
\hline ERP $->$ KK & 0.864 & 0.038 & 22.949 \\
\hline ERP $->$ PMF & 0.895 & 0.046 & 19.329 \\
\hline ERP $->$ PMI & 0.900 & 0.034 & 26.368 \\
\hline $\mathrm{PMF}->\mathrm{KK}$ & 0.733 & 0.176 & $0.753^{*}$ \\
\hline PMI -> KK & 0.877 & 0.152 & 5.759 \\
\hline
\end{tabular}

Sumber: Data yang diolah

Hasil penelitian ini mendukung temuan Alomari dkk. (2018) yang mengemukakan implementasi ERP sebagai transformasi dari sistem teknologi dan informasi perusahaan berpengaruh signifikan terhadap keunggulan kompetitif perusahaan karena dapat memberikan informasi secara lengkap, rinci dan real-time yang bisa dipakai sebagai alat pengambilan keputusan manajemen. Sementara itu, sedikit berbeda dengan hasil 
penelitian sebelumnya dari Ruivo dkk. (2014) yang menyatakan pengendalian manajemen dapat menjembatani pengaruh ERP terhadap keunggulan kompetitif. Artinya, tidak semua pengendalian manajemen dapat memediasi ketika ERP intensif digunakan perusahaan secara serta merta mempengaruhi keunggulan kompetitif, hal ini sesuai dengan hasil temuan Kallunki dkk. (2011) yang mengemukakan ada pengendalian manajemen yang dapat memediasi dan ada yang tidak dapat menjadi mediator, karena berhubungan dengan kondisi internal organisasi, budaya, regulasi. Pengendalian manajemen dapat menjadi mediator yang bagus terhadap keunggulan kompetitif dan kinerja perusahaan ketika ada penambahan atribut bisnis lain (Alomari dkk, 2018).

\section{SIMPULAN}

Hasil penelitian memberikan beberapa kesimpulan, diantaranya adalah penggunaan ERP meningkatkan kesempatan inovasi yang melibatkan pembangunan kapasitas lebih besar yang menciptakan manfaat peluang jangka panjang dan keunggulan kompetitif yang berkelanjutan sehingga hipotesis pertama diterima. Kemudian pada perusahaan, ERP berfungsi sebagai payung untuk sistem pengendalian manajemen, terlepas dari kenyataan ERP dianggap sebagai perangkat lunak teknis, namun pada faktanya ERP dapat melengkapi sistem pengendalian manajemen yang sebelumnya sudah diterapkan terlebih dahulu sebelum ERP digunakan pada perusahaan sehingga hipotesis kedua dan ke-empat diterima. Selanjutnya pengendalian formal tidak dapat menjadi mediator yang baik ketika tidak disertai dengan penambahan atribut bisnis lain, karena manajer lebih cenderung menggunakan pengendalian formal yang sudah terlebih dahulu ada sebelum ERP diterapkan pada perusahaan, maka hipotesis ketiga tidak diterima. Berbanding terbalik dengan pengendalian informal yang cenderung lebih terintegrasi dengan sistem informasi dalam menghasilkan informasi yang lebih berkualitas untuk mendukung pengambilan keputusan, maka dari itu hipotesis ke-lima diterima. Kemudian ada beberapa keterbatasan dari penelitian yang sudah dilakukan, yang pertama adalah objek penelitian ini hanya perusahaan manufaktur, maka penelitian selanjutnya diharapkan memperluas objek pada perusahaan dagang dan jasa. Kedua, penelitian ini hanya menggunakan instrumen mediator pengendalian manajemen yang masih terbatas, maka dalam penelitian selanjutnya bisa ditambahkan variabel lain yang memiliki keterkaitan hubungan yang terjadi antara ERP dan keunggulan kompetitif.

\section{DAFTAR PUSTAKA}

Alomari, I. A., Amir, A. M., Aziz, K. A., \& Auzair, S. M. (2019). “Enterprise resourceplanning system business process attributes: A research note. International Journal of Applied Research and Studies”, 5(3), 111115.

Alomari, Izzeideen A., Amizawati,Mohd Amir., Aziz,Khairul A., Auzair, Sofiah Md. (2018). "Effect of Enterprise Resource Planning Systems and Forms of Management Control on Firm's Competitive Advantage." Asian Journal of Accounting and Governance. 9: 87-98.

Anthony, Robert N. \& Govindarajan, Vijay. (2007). Sistem Pengendalian Manajemen. Jakarta: Edisi Sebelas, Buku Dua, Salemba Empat.

Appelbaum, D., Kogan, A., Vasarhelyi, M., \& Yan, Z. (2017). "Impact of business analytics and enterprise systems on managerial accounting." International Journal of Accounting Information System, 25, 2944.

Awwad, Abdulkareem S., Al Khattab, Adel A. Anchor, John R. (2013). “Competitive Priorities and Competitive Advantage in Jordanian Manufacturing." Journal of Service Science and Management.. 6, 69-79.

Bhatt, G. D., \& Grover, V. (2005). "Types of information technology capabilities and their role in competitive advantage: An empirical study." Journal of management information systems, 22(2), 253-277.

Bhimani, A., Horngren, C. T., Datar, S. M., \& Foster, G. (2008). Management and cost accounting (Vol. 1): Pearson Education. 
Botta-Genoulaz, V., Millet, P.-A., \& Grabot, B. (2005). "A survey on the recent research literature on ERP systems." Computers in industry, 56(6), 510-522.

Cäker, M. \& Siverbo, S. (2014). "Strategic alignment in decentralized organizations-The case of Svenska Handelsbanken." Scandinavian Journal of Management 30(2): 149-162.

Chae, B., \& Olson, D. L. (2013). "Business analytics for supply chain: A dynamic capabilities framework." International Journal of Information Technology \& Decision Making, 12(01), 9-26.

Chapman, C. S., \& Kihn, L.-A. (2009). "Information system integration, enabling control and performance." Accounting, Organizations and Society, 34(2), 151-169.

Chenhall, R.H. (2003). "Management control systems design within its organizational context: findings from contingency-based research and directions for the future." Accounting, Organization and Society,28(2-3), 127-168.

Chenhall. R.H. (2005). "Integrative strategic performance measurement systems, strategic alignment of manufacturing, learning and strategic outcomes: an exploratory study." Accounting, Organization and Society, 395-422.

Cugueró-Escofet, N. \& Rosanas, J.M. (2013). "The just design and use of management control systems as requirements for goal congruence." Management Accounting Research 24(1): 23-40.

Ghozali, I. (2011). Structural Equation Modeling, Metode Alternatif dengan Partial Least Square (edisi ketiga). Badan Penerbit: Universitas Diponegoro, Semarang.

Gorla, N., Somers, T. M., \& Wong, B. (2010). "Organizational impact of system quality, information quality, and service quality." The Journal of Strategic Information Systems, 19(3), 207-228.

Granlund, M., \& Malmi, T. (2002). "Moderate impact of ERPS on management accounting: a lag or permanent outcome?" Management accounting research, 13(3), 299-321.

Granlund, M. (2011). "Extending AIS research to management accounting and control issues: A research note." International Journal of Accounting Information System, 12(1), 3-19.

Griffin, P. A., \& Wright, A.M. (2015). “Commentaries on Big Data's importance for accounting and auditing." Accounting Horizon, 29(2), 377-379.

Hair Jr, J.F., Hult, G.T.M., Ringle, C. and Sarstedt, M. (2016). A primer on partial leastsquares structural equation modeling (PLS-SEM): Sage Publication.

Helsen, Z., Lybaert, N., Steijver, T., Orens, R. \& Dekker, J. (2017). "Management control systems in family firms: A review of the literature and directions for the future." Journal of Economic Survey 31(2): 410435.

Hong, P.C., Dobrzykowski, D.D. and Vonderembse, M.A. (2010), "Integration of supply chain IT and lean practices for mass customization", Benchmarking: An International Journal, Vol. 17 No. 4, pp. 561-92.

$\mathrm{Hu}$, Chuming. 2015. "Improving Competitive Advantage of Chinese Sports Brand through Brand Management." Modern Economy, , 6, 473-477.

Kallunki, J.-P., Laitinen, E. K., \& Silvola, H. (2011). "Impact of enterprise resource planning systems on management control systems and firm performance." International Journal of AccountingInformation Systems, 12(1), 20-39.

Kharabe, A. \& Lyytinen, K.J. (2012). "Is implementing ERP like pouring concrete into a company? Impact of enterprise systems on organizational agility."

Kock, N. (2015). “Common method bias in PLS-SEM: A full collinearity assessment approach.” International Journal of e-Collaboration 11(4):1-10.

Kock, N. (2011). "Using WarpPLS in e-Collaboration Studies: Mediating Effects, Control and Second Order Variables, and Algorithm Choices." International Journal of e-Collaboration, Vol. 7(3), pp. 1-13.

Lengnick-Hall, C. A., Lengnick-Hall, M. L., \& Abdinnour-Helm, S. (2004). "The role of social and intellectual capital in achieving competitive advantage through enterprise resource planning (ERP) systems." Journal of Engineering and Technology Management, 21(4), 307-330.

Mahama, H. (2006). "Management Control Systems, Cooperation and Performance in Strategic Supply Relationships: A Survey in the Mines." Management Accounting Research. 17(3):315-339.

Malmi, T. \& Brown, D. A. (2008). "Management control systems as a package Opportunities, challenges and research directions." Management accounting research 19(4): 287-300.

Molla, A., \& Bhalla, A. (2006). "ERP and competitive advantage in developing countries: the case of an Asian company." The Electronic Journal of Information System in Developing Countries, 24(1), 1-19.

Mzoughi, N., Bahri, N., \& Ghachem, M. S. (2008). "Impact of supply chain management and ERP on organizational performance and competitive advantage: Case of Tunisian companies." Journal of Global Information Technology Management, 11(3), 24-46.

Nicolaou, A. (2004a). “Firm Performance Effects In Relation To The Implementation And Use Of Enterprise Resource Planning Systems”. Journal of Information System. Vol. 18, pp. 79-105. 
Noruzy, A., Dalfard, V. M., Azhdari, B., Nazari-Shirkouhi, S., \& Rezazadeh, A. (2013). "Relations between transformational leadership, organizational learning, knowledge management, organizational innovation, and organizational performance: an empirical investigation of manufacturing firms." The International Journal of Advanced Manufacturing Technology, 64(5-8), 1073-1085.

Rom, A., \& Rohde, C. (2007). "Management accounting and integrated information systems: A literature review." International Journal of Accounting Information System, 8(1), 40-68.

Ruivo, P., Oliveira, T., \& Neto, M. (2014). "Examine ERP post-implementation stages of use and value: Empirical evidence from Portuguese SMEs." International Journal of Accounting InformationSystems, 15(2), 166-184.

Sánchez-Rodríguez, C., \& Spraakman, G. (2012). “ERP systems and management accounting: A multiple case study." Qualitative Research in Accounting \& Management 9(4): 398-414.

Scapens, R. W., \& Jazayeri, M. (2003). "ERP systems and management accounting change: opportunities or impacts? A research note." European accounting review, 12(1), 201-233.

Simons, R. (2000). Codman \& Shurtleff, Inc: planning and control system: Harvard Business School Pub.

Thomas, W.S., Baab, D and Spillan, J.E. 2012. "The Importance Of Culture Change And Change Management In Successful Implementation Of Enterprise Resource Planning Systems." Mountain Plains Journal of Business and Economics. Vol. 13, pp. 17-41.

Tsai, W., Chen, S., Hwang, E.T. and Hsu, J. (2010). "A study of the impact of business process on the ERP system effectiveness." International Journal of Busines and Management, Vol. 5 No. 9, pp. 26-37.

Widener, Sally K. (2007). "An Empirical Analysis of the Levers of Control Framework." Accounting Organization and Society. 32(7-8):757-788.

Zhang, Y., Tan, Y.W., Stormer, H. L., \& Kim, P. (2005). "Experimental observation of the quantum Hall effect and Berry's phase in graphene." Nature, 438(7065), 201.

Claudya, M., Suryani, W., \& Parulian, T. (2020). Pengaruh Sistem Pemasaran Kewirausahaan Terhadap Keunggulan Bersaing Dan Inovasi Pada UKM Kuliner Kota Medan. Jurnal Ilmiah Manajemen dan Bisnis (JIMBI), 1(2). 